\title{
Viking warrior women? Reassessing Birka chamber grave Bj.581
}

Neil Price $^{1, *}$, Charlotte Hedenstierna-Jonson ${ }^{1}$, Torun Zachrisson ${ }^{2}$, Anna Kjellström ${ }^{3}$, Jan Storå ${ }^{3}$, Maja Krzewińska ${ }^{3}$, Torsten Günther ${ }^{4}$, Verónica Sobrado ${ }^{3}$, Mattias Jakobsson ${ }^{5} \&$ Anders Götherström ${ }^{3}$

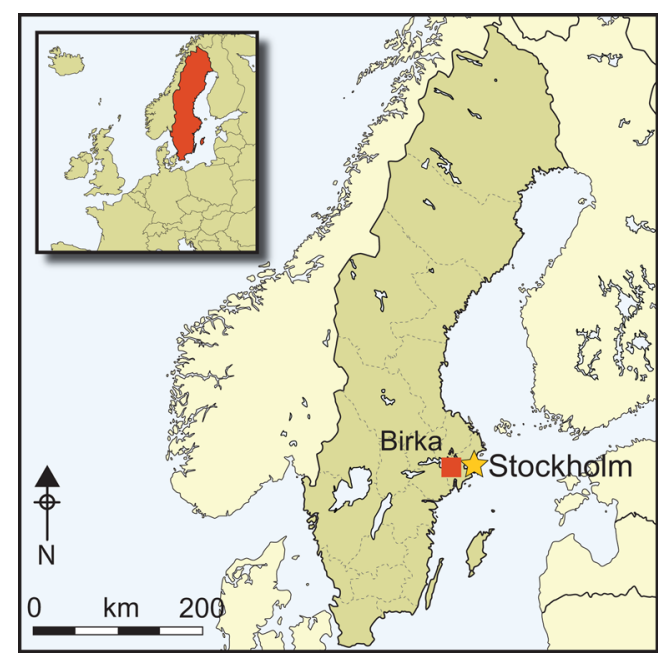

The warrior woman has long been part of the Viking image, with a pedigree that extends from the Valkyries of Old Norse prose and poetry to modern media entertainment. Until recently, however, actual Viking Age evidence for such individuals has been sparse. This article addresses research showing that the individual buried at Birka in an 'archetypal' high-status warrior grave-always assumed to be male since its excavation in 1878 - is, in fact, biologically female. Publication, in 2017, of the genomic data led to unprecedented public debate about this individual. Here, the authors address in detail the interpretation of the burial, discussing source-critical issues and parallels.

Keywords: Sweden, Birka, Viking Age, female warriors, aDNA

\section{Introduction}

The Viking Age (c. AD 750-1050) witnessed a complex Scandinavian diaspora that brought fundamental and lasting transformations to the northern world (Brink \& Price 2008). A thousand years later, the Vikings are among the most recognised—but also most

1 Department of Archaeology and Ancient History, University of Uppsala, Box 626, SE-751 26 Uppsala, Sweden

2 Upplandsmuseet, Drottninggatan 7, SE-752 10 Uppsala, Sweden

3 Department of Archaeology and Classical Studies, Stockholm University, SE-106 91 Stockholm, Sweden

4 Evolutionary Biology Centre, University of Uppsala, Norbyvägen 18A, SE-752 36 Uppsala, Sweden

5 Department of Organismal Biology, University of Uppsala, Norbyvägen 18C, SE-752 36 Uppsala, Sweden

* Author for correspondence (Email: neil.price@arkeologi.uu.se)

(C) Antiquity Publications Ltd, 2019. This is an Open Access article, distributed under the terms of the Creative Commons Attribution-NonCommercial-NoDerivatives licence (http://creativecommons.org/licenses/by-nc-nd/ $4.0 /$ ), which permits non-commercial re-use, distribution, and reproduction in any medium, provided the original work is unaltered and is properly cited. The written permission of Cambridge University Press must be obtained for commercial re-use or in order to create a derivative work.

ANTIQUITY 93367 (2019): 181-198

https://doi.org/10.15184/aqy.2018.258 
stereotyped—cultures of the prehistoric past. This problematic legacy manifests itself in countless ways, from product branding to popular entertainment, along with the recycling of Viking culture via a constant flow of international exhibitions and syntheses. Within this tangle of history, myth and cliché, however, one particular figure has been the subject of special fascination for as long as the Viking Age has been studied: the image of the warrior woman — both in the human form of the famous shield maidens and in the supernatural guise of their Valkyrie sisters.

In September 2017, the American Journal of Physical Anthropology published an article by the current authors entitled 'A female Viking warrior confirmed by genomics' (Hedenstierna-Jonson et al. 2017). It presented the results of extensive ancient DNA analysis, following earlier osteological studies. These showed that the body interred in a richly appointed Viking Age burial on the island town of Birka, Sweden, was not biologically male—as had always been assumed—but female. This was significant because the grave, which was excavated in 1878, had long been seen, and repeatedly published, as a spectacular example of a high-status warrior burial—an identity with intriguing implications in the light of our new sex determination.

In the weeks following the online publication of our article, the research was covered by more than 130 international news agencies, and was discussed across some 2200 individual online accounts, accessed by millions of followers. Altmetric ranked our article as the forty-third most frequently accessed scientific paper of some 2.2 million published globally during 2017, and placed it at 265 of the 11.7 million outputs ever scored by them (as of early September 2018). This level of interest took us by surprise and raises the important question: why did this one single grave generate such global attention?

Our objective in the present article is to bring these issues together, at greater interpretive depth than was possible in our earlier publication, which primarily focused on the genomic analysis. How should we understand this burial, what kind of person was interred there and how can we tell? Particularly, what implications does the burial have for understanding Viking Age funerary archaeology, and the ways in which we engender the societies of that time? In order to focus here on the contextualised interpretation of the grave, our article is accompanied by extensive online supplementary material (OSM) that presents the burial in greater detail, along with a discussion of source-critical issues regarding its recording, archiving and analysis. The OSM also addresses possible archaeological parallels from the Viking Age and the medieval written sources that mention female warriors.

\section{Birka and grave $B \mathbf{j} .581$}

The Viking Age settlement of Birka on the island of Björkö in Lake Mälaren, Uppland, is well known as the first urban centre in what is now Sweden. It was founded $c$. AD 750 and supported a population of perhaps 700-1000 inhabitants for the next 200 years, until its relocation to a new site (Ambrosiani 2008). The town comprised a large settled area fronting the lake, bounded by an earthen rampart with a hillfort at its south-west terminus (Figure 1). Around the perimeters of the site are several cemeteries, together containing some 3000 visible mound burials, with many more identified through geophysical prospection. Approximately 1100 of these graves were excavated in the late nineteenth century by antiquarian

(C) Antiquity Publications Ltd, 2019 


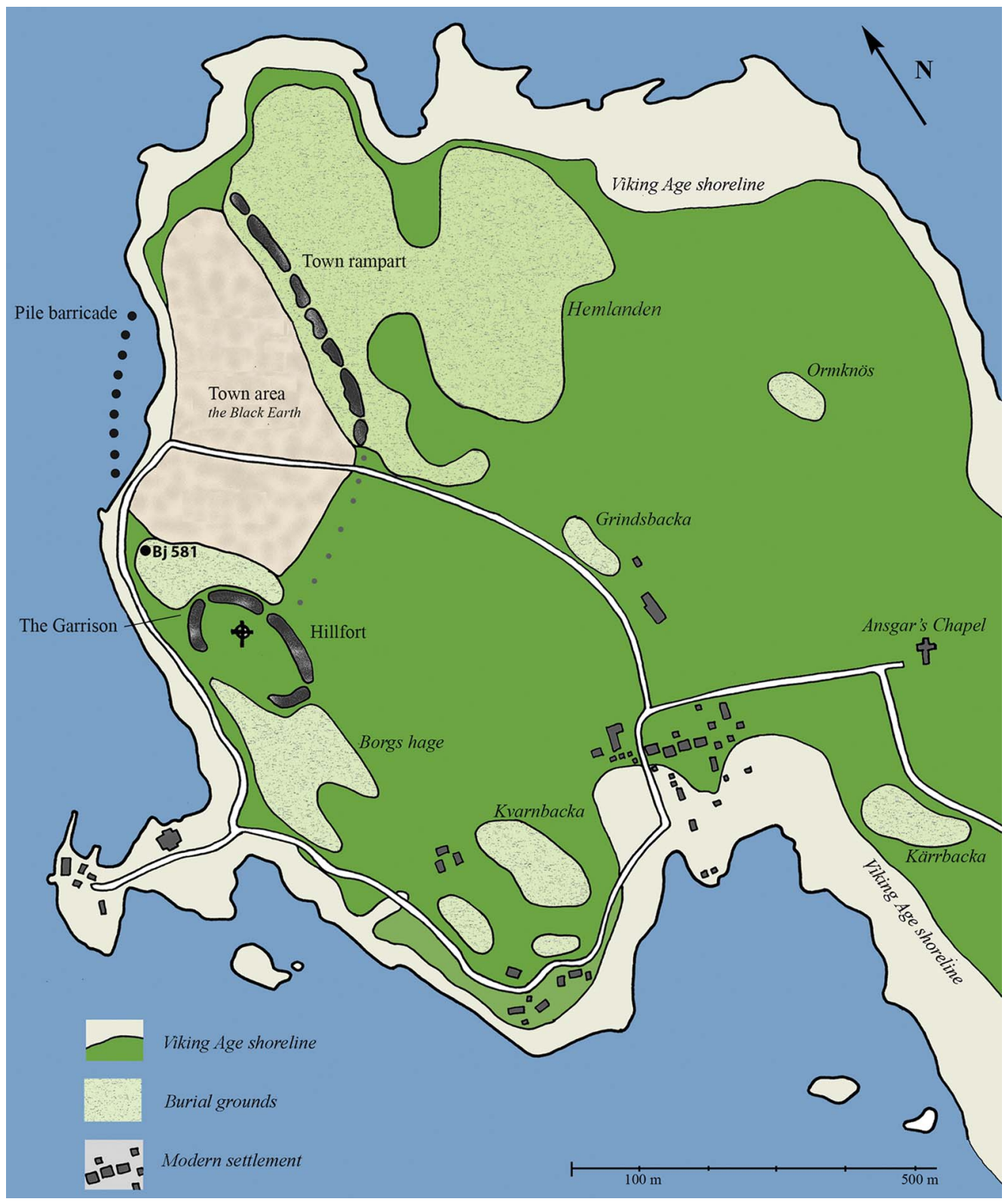

Figure 1. Plan of the Viking Age island market centre of Birka, showing the 'Black Earth' settled area, the surrounding cemeteries and the location of Bj.581 outside the hillfort gates (figure prepared by Charlotte Hedenstierna-Jonson).

Hjalmar Stolpe, using pioneering recording methods that have stood the test of time; he was, for example, one of the first archaeologists to use graph paper for field drawings (Jensen 2018: 176-79). The graves and finds were published long after the excavations in a series of landmark volumes (Geijer 1938; Arbman 1940, 1943; Gräslund 1980; Arwidsson 1984, 1986, 1989; Duczko 1985), together with specialist studies in the form of doctoral theses from the 1950 s onwards. 
One of the burials investigated by Stolpe-designated Bj.581—was recognised even at the time as being of unusual character (Figure 2); Stolpe himself described it in his unpaginated report to the Royal Academy as "perhaps the most remarkable of all the graves in this field" (1879, translated by N. Price). In an underground wooden chamber, a body had been interred, dressed in clothing with details evoking the fashions of the Eurasian Steppe; two horses, one of which was bridled for riding, had been arranged on a platform at the chamber's edge (Figure 3). The deceased individual was surrounded by a large number of weapons; a bag of gaming pieces was placed in the person's lap and a gaming board was propped up beside them. The burial was located at the extreme perimeter of the grave-field, outside the hillfort's northern gate and adjacent to the road leading from the fortress into the town. Bj.581 is, in fact, the westernmost grave at Birka, situated high on the rocky promontory overlooking the lake and originally marked by a large boulder, which would have been visible from both the settlement and the water below.

Stolpe's notes, sketches and excavation plans of Bj.581 are available online (Stolpe 18701888, 1879). The grave was fully published in the main Birka burial catalogue (Arbman 1943: 188-90, with plates in his 1940 volume) and additionally was analysed by Gräslund (1980: 27-42) in the companion publication on the funerary customs; the weapons are considered in a series of papers in Arwidsson's 1986 collection.

\section{The grave of a high-status warrior?}

Of the more than 1100 excavated burials on Birka, only 75 contain one or more offensive weapons (Thålin-Bergman 1986: 5). Bj.581 is one of only two burials from the entire island with a full complement of weapons, and has been grouped among the 20 richest graves on the site (Thålin-Bergman 1986: 5; Ringstedt 1997: 94). From the very beginning, the Bj.581 burial was interpreted as that of a high-status warrior. Weapons were present in unusual profusion and variety, suggesting the equipment of a professional—probably a mounted archer able to deploy a remarkable repertoire of fighting techniques (Figure 4). This in itself implies both skill and considerable expense: war-gear of excellent quality, intended for someone of high social standing. Conversely, there were no finds of a more domestic character, such as tools or agricultural implements.

The gaming pieces add an extra dimension (Figure 5). As individual objects, they are not uncommon in Viking Age burials, but rare as full sets with iron-bound boards (for a discussion of the Birka examples, see Selling 1940). They particularly occur in relation to military leaders; for example, being present in most of the larger boat graves (Whittaker 2006; Hall 2016), where they are employed symbolically, such as boards laid out with pieces in play (e.g. in Valsgärde boat burial 7, Arwidsson 1977: pl. 45; and Ultuna, Ljungkvist 2006: 214). The presence of a full gaming set and board in $\mathrm{Bj} .581$, and their deliberate placement in direct proximity to the body, suggests a potential command role, in addition to the high status implied by the quality of the military equipment.

The individual's clothing has also been analysed, with Birka's leading textile specialist arguing — based on a broad range of comparative data — that the person in $\mathrm{Bj} .581$ was a cavalry commander under the immediate authority of a royal war-leader (Hägg 2002: 204). The tasselled cap in particular is unusual. It was possibly manufactured in Kiev and, according to

(C) Antiquity Publications Ltd, 2019 


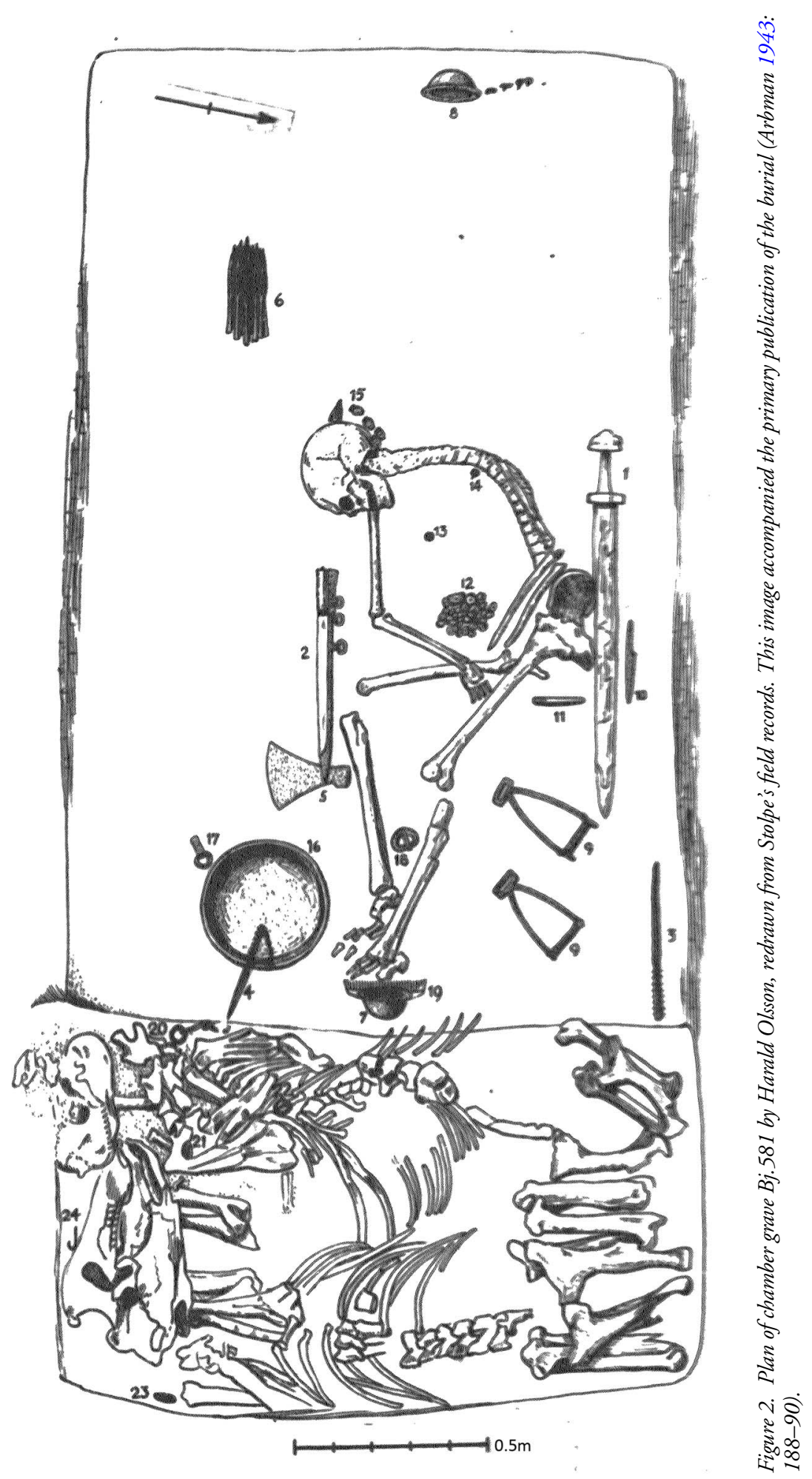

(C) Antiquity Publications Ltd, 2019 
Neil Price et al.

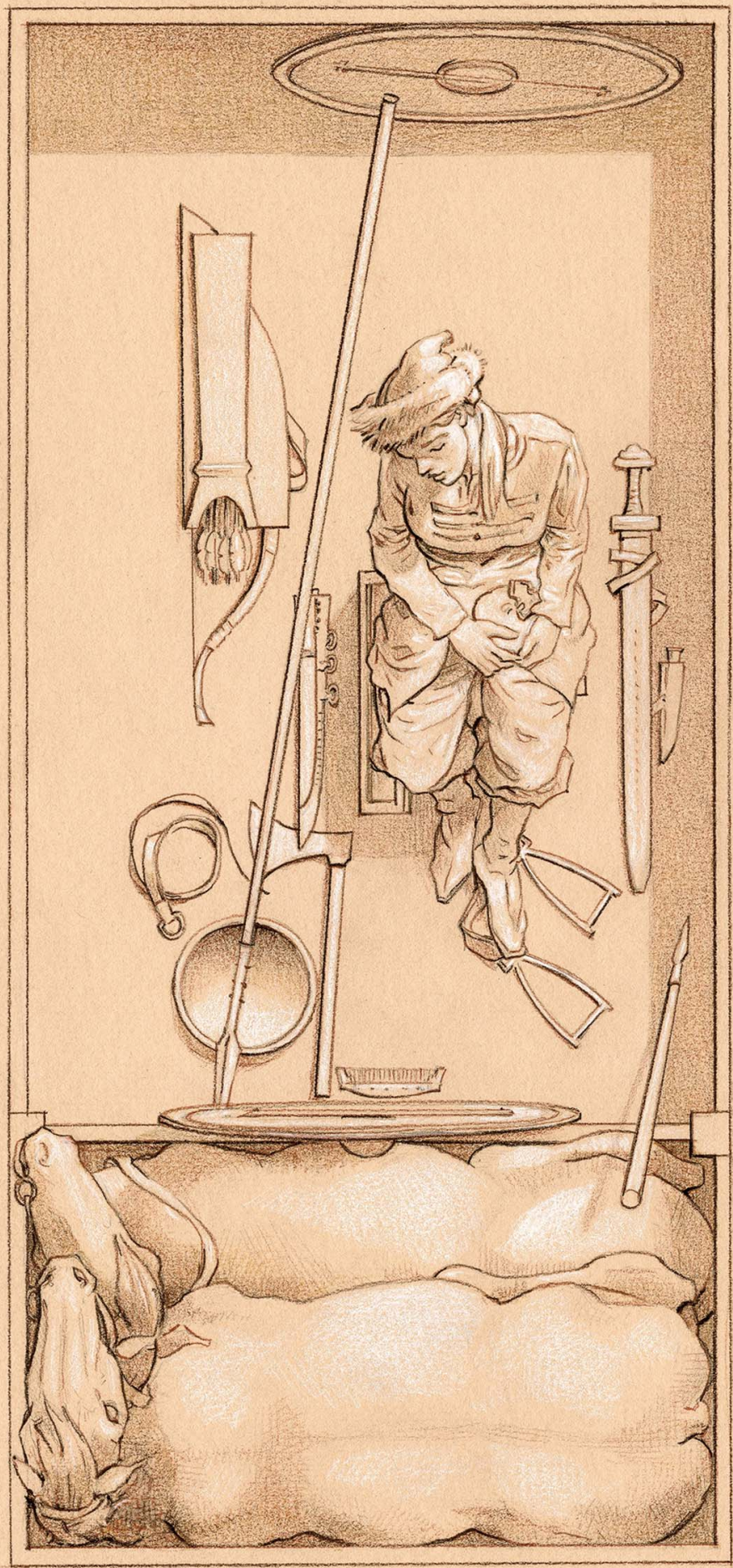

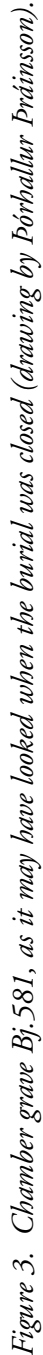

(C) Antiquity Publications Ltd, 2019 

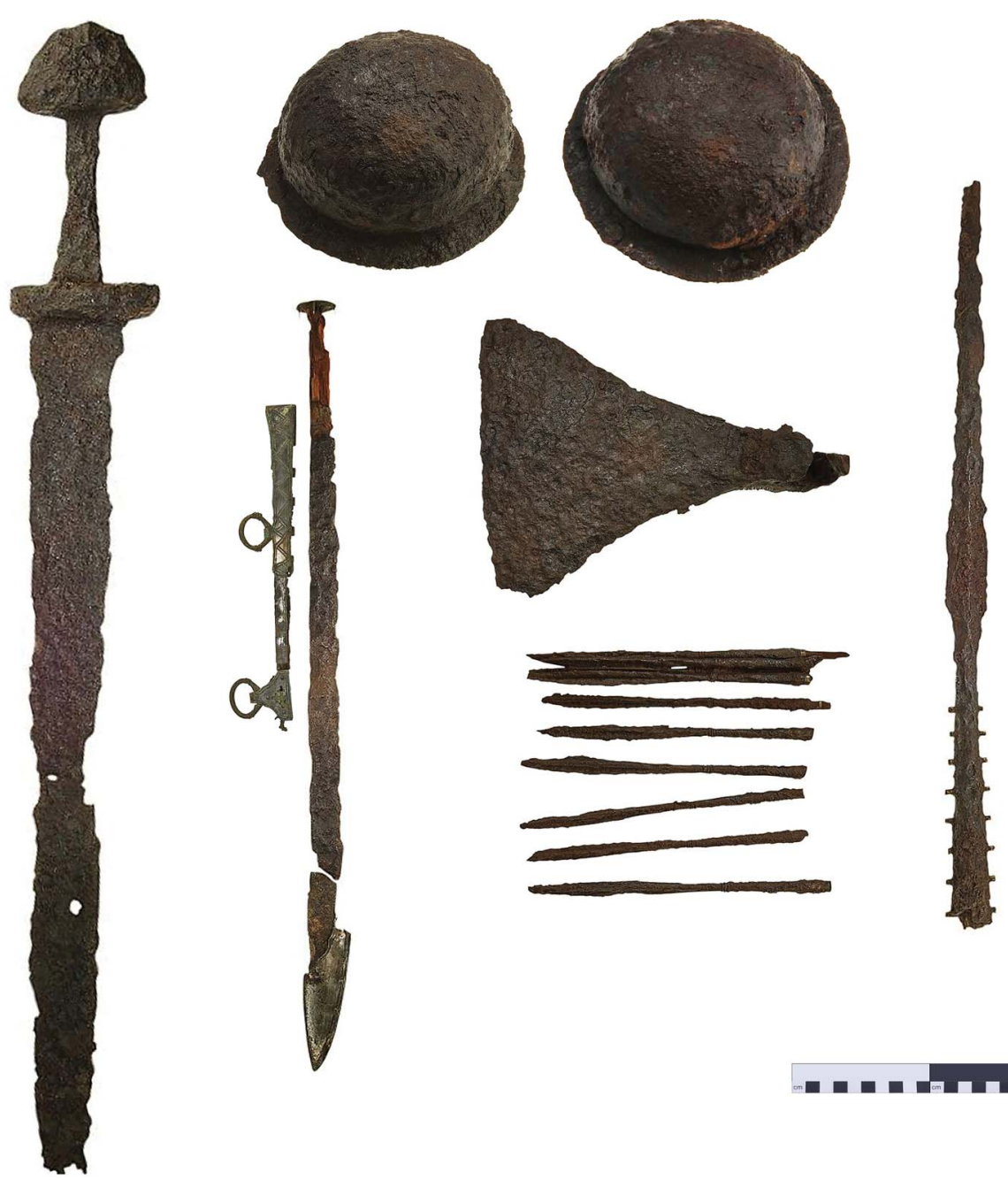

Figure 4. The weapons from chamber grave Bj.581: a sword, axe, fighting knife, two lances, two shields and 25 armour-piercing arrows (photographs courtesy of Christer Ahlin, Swedish History Museum).

Ingmar Jansson (1992: 261), was of a type made for "the leading members of society" (Figure 6).

As synthetic works on the Vikings began to appear after Birka's publication, from the 1960s onwards, Bj.581 not only continued to be consistently interpreted as a high-status warrior, but was even upheld as an archetype, a kind of 'ultimate Viking' of the tenth century (e.g. Almgren 1967: 44-45; Jones 1968: 170-71; Gräslund 1980: 41; Lofterud 1981: 16-17; Thunmark-Nylén 1981: 136-37; Ambrosiani \& Eriksson 1991: 42; Ambrosiani 1992: 17; Gräslund \& Müller-Wille 1992: 187; Magnus 2000: 19; Hall 2007: 224; Herget 2008: 76-77; Magnus \& Gustin 2009: 67; Roesdahl 2016: 162-63). As far as we are aware, this warrior interpretation has never been challenged. It should also be emphasised that the material culture of an elite warrior class on Birka has been the subject of extensive study in its

(C) Antiquity Publications Ltd, 2019 


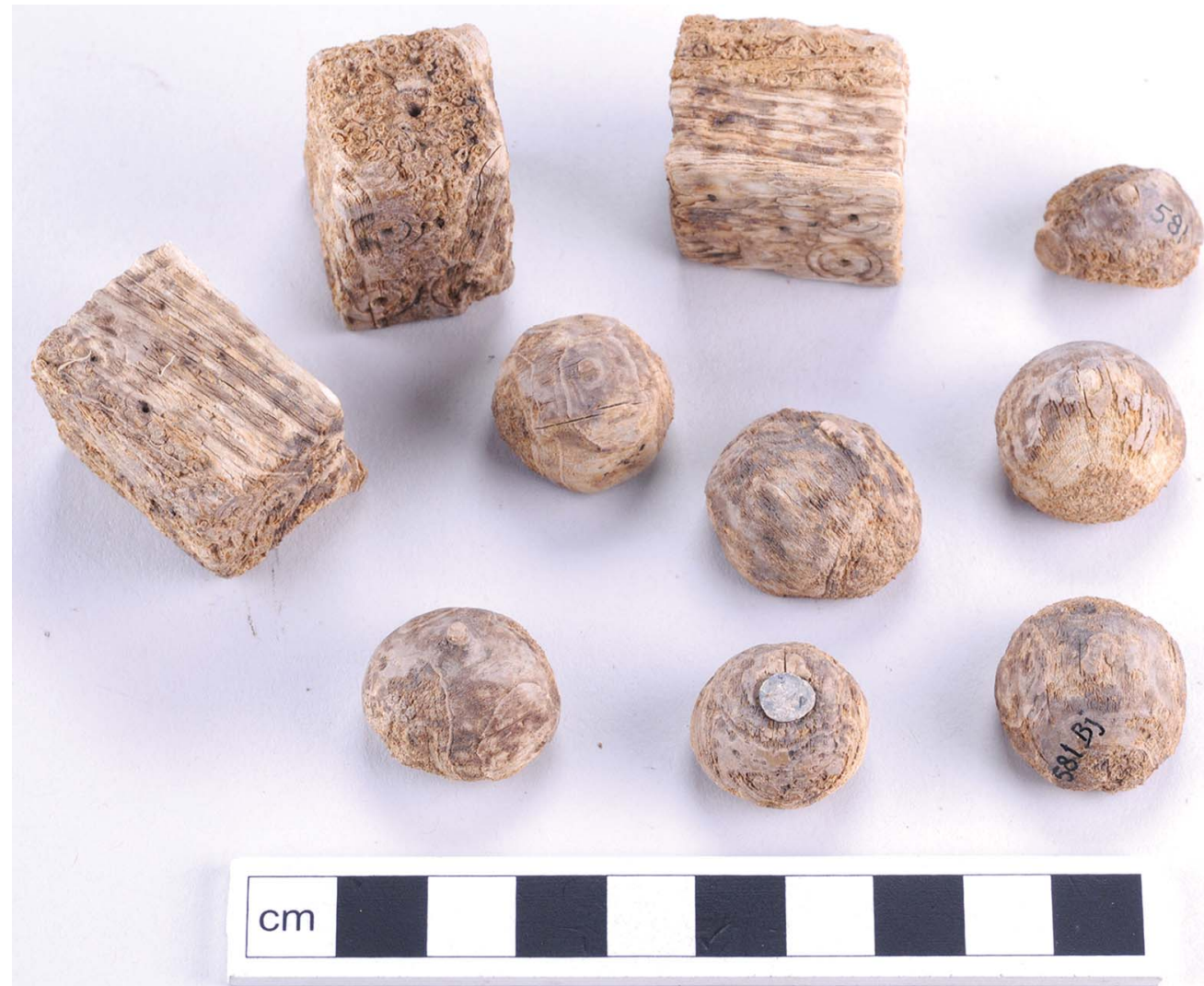

Figure 5. A selection of the gaming pieces from chamber grave Bj.581 (photograph by Charlotte Hedenstierna-Jonson).

own right, with clear overtones of eastern influence from the Rus cultural sphere (e.g. Olausson 2001; Hedenstierna-Jonson 2006; Hedenstierna-Jonson \& Holmquist Olausson 2006; Holmquist Olausson \& Olausson 2009); this provides an additional context for the Bj.581 burial.

The landscape setting of the grave itself also reinforces a warrior interpretation-being situated outside the gate of the Birka hillfort and adjacent to two other burials containing numerous weapons. This entire area has also long been regarded as having been set aside as a burial ground for the rich (Figure 7; Arbman 1939: 75; for the weapon burials, Bj.495 and Bj.496, see Thalin-Bergman 1986). In 1998, the nearby discovery of the so-called 'garrison' building, a 20m-long hall containing a unique assemblage of weaponry, further strengthened this spatial link (Kitzler 2000; Holmquist Olausson \& Åhlfeldt 2002). This structure had been burned during an attack, preserving pieces of shields that seem to have been hanging on the walls, together with fragments of at least nine spears, three swords, two axes, two fighting knives, more than 50 arrows and dozens of rare pieces of both chainmail and lamellar armour. In addition, some 300 knives had been incorporated into the floors and walls of the structure, while the terrace on which it was raised contained a dedicatory deposit of lanceheads; in essence, the structure was a hall built of blades, founded on spears.

(C) Antiquity Publications Ltd, 2019 


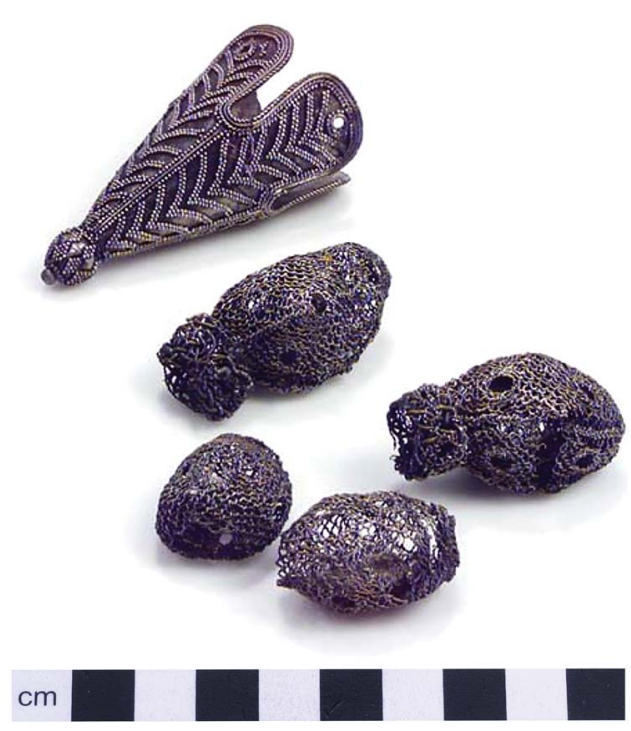

Figure 6. The silver terminal and tassels from the cap in chamber grave Bj.581 (photograph courtesy of Christer Ahlin, Swedish History Museum).
The hillfort contained no known structures, perhaps functioning as a place of refuge. The hall has therefore been interpreted as part of the garrison, housing the fort's defenders in the course of their regular duties (Holmquist Olausson \& Åhlfeldt 2002).

The assumption that the buried individual in $\mathrm{Bj} .581$ must have been a man began during the excavation itself-as Stolpe clearly states in his field notes; this interpretation has persisted ever since, as reproduced in the works cited above. In addition to the presence of weaponry, normatively taken to indicate a male, this sex attribution was based on the absence of jewellery, weaving equipment and other objects conventionally associated with women. It is important to remember that when Bj.581 was recorded, male biological sex was not only conflated with a man's gendered identity, but also that warriorhood was presumed to be an exclusively masculine pursuit; the same interpretation would undoubtedly have been made had no human bone survived at all.

The immediate environs of $\mathrm{Bj} .581$ have received far less attention. The two other weapon graves, Bj.495 and Bj.496, for example, have been noted above; both were chambered inhumations, one of which included a horse burial. The closest grave of all, $\mathrm{Bj} .608$, appears to be that of a child, buried without any associated objects (Arbman 1943: 201; Gräslund 1980: 11). Immediately to the east is Bj.585 (Arbman 1943: 191-92), which would traditionally be interpreted as a high-status woman's burial, due to the presence of a jewellery set. A recent isotopic study has shown that this person probably originated in Denmark (Price et al. 2018: 36). We do not know the relationship, if any, between these four adults and the child, but there is clearly scope for further study.

Given this weight of interpretation and assumption, accumulating over many decades, the results of our new analysis of Bj.581 prompted interesting questions. The data and analyses for determination of the sex of the buried individual are presented in our 2017 article, and in the OSM for both that paper and the present one. The OSM also details-and countersthe objections that were immediately raised, as to whether we had analysed the correct skeleton, and whether there had been a second body in the grave. The simple and secure conclusion is that we have the right individual, who was buried alone, and that this person has been proven to be biologically female.

\section{The implications}

It is worth stating that, despite the controversy following our 2017 article, the human and artefactual contents of grave $\mathrm{Bj} .581$ remain entirely unchanged since their excavation in

(C) Antiquity Publications Ltd, 2019 


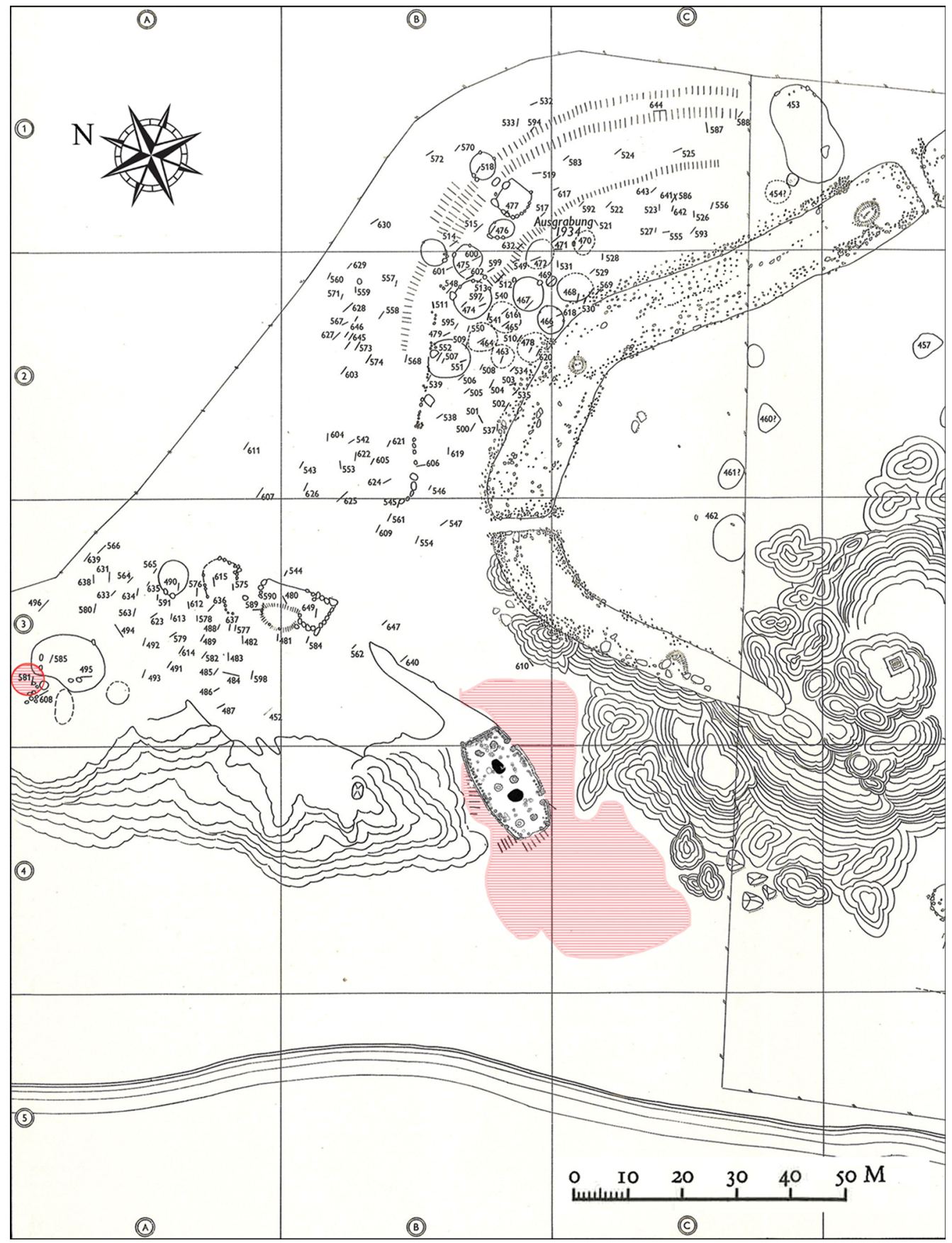

Figure 7. Bj.581 shown in relation to the Birka hillfort and the 'garrison' hall (figure by Charlotte Hedenstierna-Jonson incorporating material courtesy of Lena Holmquist, overlain on the 1888-1889 base survey by J.J. Nordstrand, Antiquarian Topographical Archives, Stockholm).

(C) Antiquity Publications Ltd, 2019 
1878. The buried person has always carried two X chromosomes, even if this was unknown before our recent work; the occupant of Bj.581 will never be biologically male again. The research history of the grave provides an instructive case study at the intersection of evidential constraints (e.g. Wylie 1992), the influence of contemporary epistemological positions (e.g. Gero 1985, 1991; Joyce 2008) and the phenomenon of cumulative false assumptions in forensic decision-making (e.g. Nakhaeizadeh et al. 2014; Dror et al. 2017).

The archaeology of death and burial has a rich general literature of theoretical interpretation (e.g. Parker Pearson 1999; Nilsson Stutz \& Tarlow 2013), and has been explored in depth for the early medieval period, particularly in an Anglo-Saxon context (e.g. Williams 2006; Sayer \& Williams 2009). We strongly believe that the interpretation of all burials must be undertaken with care, and that we should be naturally cautious in assuming that items buried with the dead represent their own possessions, or reflect their activities in life. This is crucially important in relation to gender, which has long been identified as a problematic aspect of funerary archaeology, as traditionally interpreted. Many scholars have wrestled with the need to reanalyse burials, and with the consequences of doing so (e.g. Arnold 1991; Dowson 2006; Geller 2009); the issues that we face with Bj.581 are far from new. Too often concepts have been collapsed, and the crucial distinctions between sex and gender have been blurred (Ghisleni et al. 2016). In the context of Bj.581, this naturally connects to deeper studies of women, gender and social norms, specifically in Viking Age Scandinavia, both in archaeology and text (e.g. Sørensen 1983; Jesch 1991, 2015: 87118; Jochens 1995, 1996; Arwill-Nordbladh 1998; Anderson \& Swenson 2002; Solli 2002; Back Danielsson 2007; Moen 2011; Friðriksdóttir 2013; Coleman \& Løkka 2014; Hauptmann 2014; Raffield et al. 2018). There are also useful and well-referenced studies of the archaeological identification of female warriors more widely (e.g. Jordan 2009), which identify many of the same issues that we have encountered, including interpretive tropes that see such individuals in terms that are purely relative to men (Jordan (2009: 97-98) refers to 'the Appendage', 'the Symbol' and 'the Honorary Male', for example). It must be clearly stated that we are only beginning to discern the overarching patterns of normative-and deviant-mortuary practices in the Viking Age, as the literature on the funerary record is vast and covers tens of thousands of excavated graves (e.g. Svanberg 2003; Gansum 2004; Andersson 2005; Price 2008a \& b, 2010, 2014; Gardeła 2013).

Can we be sure that the person in Bj.581 was a woman, in a gendered sense? No, we cannot. She may have taken on a man's social role, while retaining a feminine identity (cf. Clover 1993). Queer theory also provides a potentially fruitful means of engaging with this individual, and their sense of self may have been — in our terms — non-binary or gender-fluid; identity may have been something to negotiate, to choose and re-choose on a daily basis (e.g. Solli 2002; Reeder 2008; Geller 2017). Of all the many suggestions that we have received since our 2017 article, both from academics and the public alike, probably the most common has been a transgendered reading. While we understand this line of thinking in the context of contemporary social debates, it should be remembered that this is a modern politicised, intellectual and Western term, and, as such, is problematic (some would say impossible) to apply to people of the more remote past. All this is also inevitably speculative, considering the limitations of the archaeological material. There are many other possibilities across a wide gender

(C) Antiquity Publications Ltd, 2019 
spectrum, some perhaps unknown to us, but familiar to the people of the time. We do not discount any of them.

Can we prove that the occupant of Bj.581 was a warrior? This depends on definitions. We can first consider the non-literal interpretations. Perhaps she was a farmer, a housewife, a fisherwoman, a merchant, a craftworker, a poet or a slave, buried with expensive and dangerous things that did not belong to her, and with none of her own possessions. Perhaps she was, for some reason, interred with objects that conferred a proxy identity that she never had when alive. Equally, she may have lived as a warrior, but in a symbolic sense. In this light, we should also consider other early medieval cemeteries, both in Scandinavia and beyond, where we find people buried with what were clearly non-functional weapons, either unfinished or in such poor repair as to be useless. Similarly, we find operational weapons interred with individuals such as young children, who could never have physically wielded them (e.g. Lindqvist 2004: 76-77). There are more variants on a similar theme. What is important here, however, is that all these combinations of artefacts and individuals - whether preserved from life or bestowed after death-refer to the concept of bearing arms, the gendered notion of 'warrior-ness' (the extensive literature on Viking 'warrior' ideology, ritual and burial includes Jakobsson 1992; Nørgård Jørgensen \& Clausen 1997; Nørgård Jørgensen 1999; Biddle \& Kjølbye-Biddle 2001; Price 2002; Pedersen 2014; Harrison \& Ó Floinn 2014). To be a warrior was, at least in part, a social construct, and not necessarily directly connected to entering actual combat. If such a thing applied to the person in Bj.581, we do not know exactly how this operated, and it is possible that we are just seeing the high-end 'straight-to-Valhöll' option from the Birka funeral directors, but it would have made this individual a warrior nonetheless.

Despite these possibilities, however, we contend that there is far better contextual evidence for the more literal and traditional interpretation, as summarised above. The person in Bj.581 was buried in a grave full of functional weapons and war-gear (and little else), in close proximity to other burials with weapons, next to a building saturated with weapons, outside the gate of a fortress. Furthermore, the interment took place at a time when the hillfort and 'garrison' were at their zenith. Many other interpretations of both funerary treatment and gender are possible, but Occam's razor would suggest that to reach for them as a first resort is to attempt to 'explain away' what seems to be the most obvious and logical conclusion. In our opinion, Bj.581 was the grave of a woman who lived as a professional warrior and was buried in a martial environment as an individual of rank (Figure 8).

In our 2017 article—as its title indicates—we strongly followed the same military reading as has been proposed for Bj.581 by a long series of archaeological authorities, and for the same sensible reasons that are far from arbitrary. In doing so, we find no problem in adjusting for the new sex determination. To those who do take issue, however, we suggest that it is not supportable to react only now, when the individual has been shown to be female, without explaining why neither the warrior interpretations nor any supposed source-critical factors were a problem when the person in $\mathrm{Bj} .581$ was believed to be male.

\section{Viking warrior women: fact or fiction?}

Birka grave Bj.581 suggests to us that at least one Viking Age woman adopted a professional warrior lifestyle and may well have been present on the battlefield. We would be very (C) Antiquity Publications Ltd, 2019 


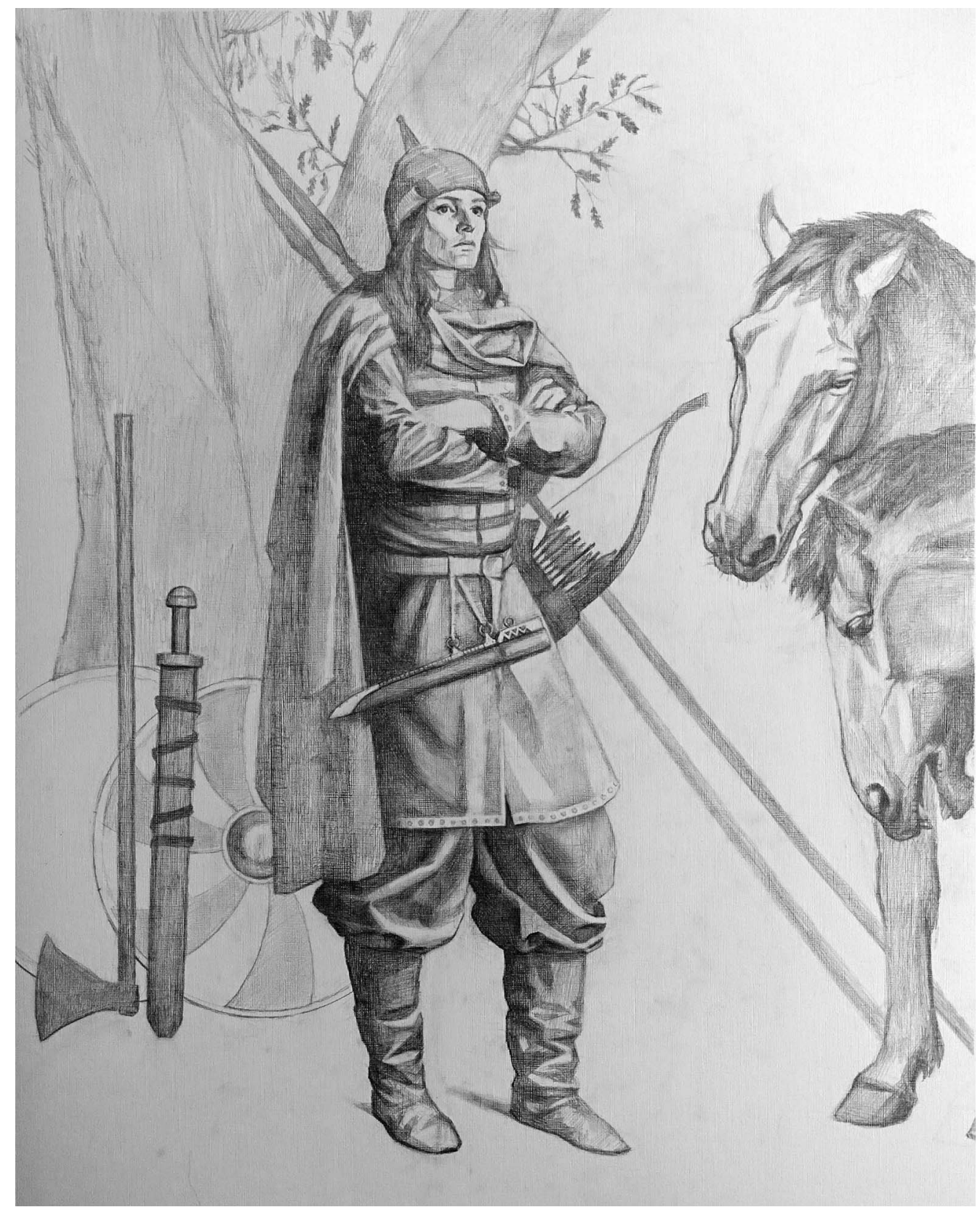

Figure 8. The occupant of Bj.581, reconstructed as a female warrior of high status. Clothing details are based on material from the Birka chamber burials and on the contemporaneous graves from Moshchevaya Balka in the North Caucasus (Knauer 2001) (drawing by Tancredi Valeri).

surprised if she was alone in the Viking world; other women may have taken up arms in the same seasonal or opportunistic context as many male Viking raiders. A few may have risen to positions of command-indeed, the quality of the individual's clothing, and the presence of the gaming set, implies that she may have been one of them.

(C) Antiquity Publications Ltd, 2019 
In interpreting such individuals, we must question our assumptions and categories. What constitutes a weapon or a warrior, and how might we tell? What links do we make between buried individuals and the items accompanying them? What are our perceptions of gender and personal identity? How do we extrapolate from archaeologically recorded individuals to society in general? We must be especially aware that such perceptions are ours and not necessarily those of Viking Age people. Similarly, such critique must be applied broadly, and not just in contexts where the implications are inconvenient for preconceived interpretations. In that light, we also need to examine ourselves as scholars-our own biases and prejudices — asking what we are prepared to find acceptable in the past, and why.

We have not 'gone looking' for female Viking warriors. The case of Bj.581 arose after the discrepancy in sex determination was discovered through Kjellström's original study on the Mälar population (see the OSM); since then, we have followed the trail of data and analysis. Similarly, the DNA work that confirmed the female sex of the individual was part of a much larger genomic study, not specifically directed at Bj.581. We feel no intrinsic need for there to have been a female warrior buried in the grave, nor for such individuals to have existed more widely. We simply find it interesting that this seems to have been the case. In the course of our research — and even more so after the 2017 publication—it has been enlightening to discover how many people apparently need that not to be so.

Time will prove us right or wrong, but we think it probable that more Viking Age female warriors will be found in the archaeological record-either as new discoveries or as reinterpretations of old finds, perhaps using genomics, as we have done. Given the enormous numbers of buried individuals from this period that have been sexed only indirectly using associated artefacts, it is even possible that female warriors will eventually appear in some quantity. Currently, the figure of the woman with weapons seems to be an exception, but this does not mean that she can be deconstructed out of existence-especially on the basis of Pavlovian scepticism. She adjusts and nuances our interpretations, and challenges our stereotypes. She adds still further dimensions to our understanding of the Viking Age as a time of critical cultural transformation and social encounter.

Clearly, the investigation of Bj.581 has relevance for archaeological studies of gender (including feminist and queer theory), violence, mortuary behaviour, symbolism and many other fields, both in general and with specific reference to the Viking Age. At the same time, the relatively meagre data from this single, unusual (and exceptional?) grave cannot be made to bear an infinite burden of expectation and agenda - whether in support of, or in resistance to, our conclusions. This article is not, and for practical reasons cannot be, an attempt to achieve a greater understanding of Viking Age sex/gender systems in their totality. Instead, this is a case study that, in some ways, presents more questions than answers, but which also opens up previously unexpected possibilities. Not least, we stand before the collective corpus of excavated Viking Age burials with an urgent task of patient and careful reassessment, in relation to not only gender, but also concerning the social signals encoded within every aspect of funerary ritual. In the specific case of Bj.581, of course, one may draw different conclusions, but the integrity of the grave and the biological sex determination are secure. It is now for others to decide how they deal with the wider implications.

(C) Antiquity Publications Ltd, 2019 


\section{Acknowledgements}

The research project on Bj.581 is led by Charlotte Hedenstierna-Jonson, under the dual auspices of the 'ATLAS of 1000 Ancient Genomes' and 'The Viking Phenomenon' projects at the Universities of Stockholm and Uppsala. Funding is provided by the Swedish Foundation for Humanities and Social Sciences (grant M13-0904:1), and by the Swedish Research Council (grants 2013-1905 and 2015-00466). We gratefully acknowledge the following for their comments and assistance during the writing of this paper: Clare Downham, Itiel Dror, Marianne Hem Eriksen, Leszek Gardeła, Alban Gautier, Cat Jarman, Marianne Moen, Anne Pedersen, Peter Pentz, Anita Saukel, Lars Stenvik, Amica Sundström, Pórhallur Práinsson, Tancredi Valeri, Kenton Vaughan, Marit Synnøve Vea, Anna Wessman, Gareth Williams and two anonymous reviewers. In addition, we wish to thank the seminar and lecture audiences who have contributed valuable feedback over the years of the project. Lastly, particular thanks go to Terry Gunnell and the University of Iceland for a critical period of calm in which this paper could be finished.

\section{Supplementary material}

To view supplementary material for this article, please visit https:/doi.org/10.15184/aqy. 2018.258

\section{References}

Almgren, B. 1967. Vikingen. Stockholm: Wahlström \& Wikstrand.

Ambrosiani, B. 1992. Birka. Stockholm: Riksantikvarieämbetet.

- 2008. Birka, in S. Brink \& N. Price (ed.) The Viking world: 94-100. London: Routledge.

Ambrosiani, B. \& B.G. Eriksson. 1991. Birka vikingastaden. Stockholm: Wiken.

Andersson, G. 2005. Gravspråk som religiös strategi: Valsta och Skälby i Attundaland under vikingatid och tidig medeltid. Stockholm: Riksantikvarieämbetet.

Anderson, S.M. \& K. Swenson (ed.). 2002. Cold counsel: women in Old Norse literature and mythology. London: Routledge.

Arbman, H. 1939. Birka: Sveriges äldsta handelsstad. Stockholm: Thule.

- 1940. Birka I: die Gräber. Tafeln. Stockholm: Vitterhetsakademien.

- 1943. Birka I: die Gräber. Text. Stockholm: Vitterhetsakademien.

Arnold, B. 1991. The deposed princess of Vix: the need for an engendered European prehistory, in D. Walde \& N.D. Willows (ed.) The archaeology of gender: 366-74. Calgary: University of Calgary Archaeological Association.

Arwidsson, G. 1977. Valsgärde 7. Uppsala: Uppsala University Press.

Arwidsson, G. (ed.). 1984. Birka II:1 Systematische Analysen der Gräberfunde. Stockholm:

Vitterhetsakademien.
- 1986. Birka II:2 Systematische Analysen der Gräberfunde. Stockholm: Vitterhetsakademien.

- 1989. Birka II:3 Systematische Analysen der Gräberfunde. Stockholm: Vitterhetsakademien.

Arwill-NordbladH, E. 1998. Genuskonstruktioner i nordisk vikingatid. Gothenburg: Gothenburg University.

Back Danielsson, I.-M. 2007. Masking moments: the transitions of bodies and beings in Late Iron Age Scandinavia. Stockholm: Stockholm University.

Biddle, M. \& B. Kjølbye-Biddle. 2001. Repton and the 'great heathen army', $873-4$, in J. Graham-Campbell, R. Hall, J. Jesch \& D.N. Parsons (ed.) Vikings and the Danelaw: 45-96. Oxford: Oxbow.

Brink, S. \& N. Price (ed.). 2008. The Viking world. London: Routledge. https://doi.org/10.4324/9780203412770

Clover, C.J. 1993. Regardless of sex: men, women and power in early medieval Europe. Representations 44: 1-28. https://doi.org/10.1525/rep.1993.44.1. 99p0191t

Coleman, N. \& N. LøkKa (ed.). 2014. Kvinner $i$ vikingtid. Oslo: Scandinavian Academic.

Dowson, T. 2006. Archaeologists, feminists and queers: sexual politics in the construction of the past, in P. Geller \& M. Stockett (ed.) Feminist anthropology: past, present, and future: 89-102. Philadelphia: University of Pennsylvania Press.

Dror, I.E., R. Morgan, C. Rando \& S. NAKHAEIZADEH. 2017. The bias snowball and the bias cascade effects: two distinct biases that

(C) Antiquity Publications Ltd, 2019 
may impact forensic decision making. Journal of Forensic Science 62: 832-33. https://doi.org/10.1111/1556-4029.13496

Duczko, W. 1985. Birka V: the filigree and granulation work of the Viking period. Stockholm: Kungl. Vitterhetsakademien.

FriĐriksdótTir, J.K. 2013. Women in Old Norse literature: bodies, words and power. New York: Palgrave Macmillan. https://doi.org/10.1057/9781137118066

Gansum, T. 2004. Hauger som konstruksjoner: arkeologiska forventninger gjennom $200 \mathrm{a}$ ir. Gothenburg: Gothenburg University.

GardeŁa, L. 2013. The dangerous dead? Rethinking Viking Age deviant burial, in L. Słupecki \& R. Simek (ed.) Conversions: looking for ideological change in the early Middle Ages: 99-136. Vienna: Fassbaender.

GeIjer, A. 1938. Birka III: die Textilfunde aus den Gräbern. Stockholm: Vitterhetsakademien.

Geller, P.L. 2009. Bodyscapes, biology, and heteronormativity. American Anthropologist 111: 504-16.

https://doi.org/10.1111/j.1548-1433.2009. 01159.x

GeLLER, P.L 2017. The bioarchaeology of socio-sexual lives: queering common sense about sex, gender, and sexuality. New York: Springer.

Gero, J. 1985. Socio-politics and the woman-athome ideology. American Antiquity 50: 342-50. https://doi.org/10.2307/280492

- 1991. Genderlithics: women's roles in stone tool production, in J. Gero \& M. Conkey (ed.)

Engendering archaeology: women and prehistory: 163-93. Cambridge (MA): Wiley-Blackwell.

Ghisleni, L., A.M. Jordan \& E. Fioccoprile (ed.). 2016. 'Binary binds': deconstructing sex and gender dichotomies in archaeological practice. Journal of Archaeological Method and Theory 23: 765-87. https://doi.org/10.1007/s10816-016-9296-9

GräsLund, A.-S. 1980. Birka IV: the burial customs. Stockholm: Vitterhetsakademien.

Gräslund, A.-S. \& M. Müller-Wille. 1992. Burial customs in Scandinavia during the Viking Age, in E. Roesdahl \& D.M. Wilson (ed.) From Viking to crusader: Scandinavia and Europe 800 1200: 186-87. Uddevalla: Nordic Council of Ministers.

HägG, I. 2002. Aussagen der Texdlfunde zu den gesellschaftlichen und wirtschaftlichen Verhältnissen fruhstädtischer Zentren in Nordeuropa - die Beispiele Haithabu und Birka, in K. Brandt, M. Müller-Wille \& C. Radtke (ed.) Haithabu und die frühe Stadtentwicklung im nördlichen Europa: 181-218. Neumünster: Wachholz.

HaLL, M. 2016. Board games in boat burials: play in the performance of migration and Viking Age mortuary practice. European Journal of Archaeology 19: 439-55. https://doi.org/10.1080/14619571.2016.1175774

HaLL, R. 2007. Exploring the world of the Vikings. London: Thames \& Hudson.

Harrison, S. \& R. Ó Floinn. 2014. Viking graves and grave-goods in Ireland. Dublin: National Museum of Ireland.

Hauptmann, K. 2014. Slaget om vikingatiden-en ojämn kamp mot forna stereotyper, in K. Hauptmann \& K. Näversköld (ed.) Genusförbart: inspiration, erfarenheter och metoder för mångfald i museiarbete: 61-71. Lund: Nordic Academic.

Hedenstierna-Jonson, C. 2006. The Birka warrior: the material culture of a martial society. Stockholm: Stockholm University.

Hedenstierna-Jonson, C. \& L. Holmquist Olausson. 2006. The Oriental mounts from Birka's garrison: an expression of warrior rank and status. Stockholm: Vitterhetsakademien.

Hedenstierna-Jonson, C., A. KJellström, T. Zachrisson, M. Krzewińska, V. Sobrado, N. Price, T. Günther, M. Jakobsson, A. Götherström \& J. STORÅ. 2017. A female Viking warrior confirmed by genomics. American Journal of Physical Anthropology 164: 853-60. https://doi.org/10.1002/ajpa.23308

Herget, M. 2008. Reitergrab aus Birka, in A. Koch (ed.) Die Wikinger: 76-77. Speyer: Historisches Museum der Pfalz.

Holmquist Olausson, L. \& L.K. Ånlfeldt. 2002. Krigarnas hus: arkeologisk undersökning av ett hallhus I Birkas Garnison (Archaeological Research Laboratory Report 4). Stockholm: Stockholm University.

Holmquist Olausson, L. \& M. Olausson (ed.). 2009. The martial society: aspects of warriors, fortifications and social change in Scandinavia. Stockholm: Stockholm University.

JAKoBsson, M. 1992. Krigarideologi och vikingatida svärdstypologi. Stockholm: Stockholm University.

(C) Antiquity Publications Ltd, 2019 
Jansson, I. 1992. Cap mounts, in E. Roesdahl \& D.M. Wilson (ed.) From Viking to crusader: Scandinavia and Europe 800-1200: 261. Uddevalla: Nordic Council of Ministers.

Jensen, O.W. 2018. På spaning efter det förflutna: en historia om arkeologiskt fältarbete I Sverige 16001900. Stockholm: Vitterhetsakademien.

Jesch, J. 1991. Women in the Viking Age. Woodbridge: Boydell.

- 2015. The Viking diaspora. London: Routledge.

Jochens, J. 1995. Women in Old Norse society. Ithaca (NY): Cornell University Press.

- 1996. Old Norse images of women. Philadelphia: University of Pennsylvania Press.

Jones, G. 1968. A history of the Vikings. Oxford: Oxford University Press.

JORDAN, A. 2009. I am no man: a study of warrior women in the archaeological record. Field Notes: a Journal of Collegiate Anthropology 1: 94-111.

Joyce, R. 2008. Ancient bodies, ancient lives: sex, gender, and archaeology. London \& New York: Thames \& Hudson.

Kitzler, L. 2000. Odensymbolik i Birkas garnison. Fornvännen 95: 13-21.

Knauer, E.R. 2001. A man's caftan and leggings from the North Caucasus of the eighth to tenth century: a conservator's report. Metropolitan Museum Journal 36: 85-124. https://doi.org/10.2307/1513059

LINDQvisT, M. 2004. Barn på vikingatiden. Gotländsk Arkiv 76: 74-77.

Ljungkvist, J. 2006. En hiar atti rikR. Om elit, struktur och ekonomi kring Uppsala och Mälaren under yngre järnålder. Uppsala: Uppsala University Press.

Lofterud, C. 1981. Björkö-Birka. Uddevalla: Risbergs.

Magnus, B. 2000. Birka. Stockholm: Riksantikvarieämbetet.

Magnus, B. \& I. Gustin. 2009. Birka och Hovgården. Stockholm: Riksantikvarieämbetet.

Moen, M. 2011. The gendered landscape: a discussion on gender, status and power in the Norwegian Viking Age landscape (British Archaeology Reports International series 2207). Oxford: British Archaeological Reports.

Nakhaeizadeh, S., I.E. Dror \& R.M. Morgan. 2014. Cognitive bias in forensic anthropology: visual assessment of skeletal remains is subject to confirmation bias. Science and Justice 54: 208-14. https://doi.org/10.1016/j.scijus.2013.11.003
Nilsson Stutz, L. \& S. Tarlow (ed.). 2013. The Oxford handbook of the archaeology of death and burial. Oxford: Oxford University Press. https://doi.org/10.1093/oxfordhb/ 9780199569069.001 .0001

Nørgård Jørgensen, A. 1999. Waffen und Gräber. Typologische und chronologische Studien zu skandinavischen Waffengräbern 520/30 bis 900 $n$. Chr. Copenhagen: Royal Society of Northern Antiquaries.

Nørgård Jørgensen, A. \& B.L. Clausen (ed.). 1997. Military aspects of Scandinavian society in a European perspective, AD 1-1300. Copenhagen: National Museum of Denmark.

Olausson, M. (ed.). 2001. Birkas krigare. Stockholm: Stockholm University.

Parker-Pearson, M. 1999. The archaeology of death and burial. Sutton: Stroud.

Pedersen, A. 2014. Dead warriors in living memory: a study of weapon and equestrian burials in Viking-Age Denmark, AD 800-1000. Copenhagen: National Museum of Denmark.

Price, N. 2002. The Viking way: religion and war in Late Iron Age Scandinavia. Uppsala: Uppsala University.

- 2008a. Dying and the dead: Viking Age mortuary behaviour, in S. Brink \& N. Price (ed.) The Viking world: 257-73. London: Routledge.

-2008b. Bodylore and the archaeology of embedded religion: dramatic licence in the funerals of the Vikings, in D.M. Whitley \& K. Hays-Gilpin (ed.) Belief in the past: theoretical approaches to the archaeology of religion: 143-65. Walnut Creek (CA): Left Coast.

- 2010. Passing into poetry: Viking Age mortuary drama and the origins of Norse mythology. Medieval Archaeology 54: 123-56. https://doi.org/10.1179/ 174581710X12790370815779

- 2014. Nine paces from Hel: time and motion in Old Norse ritual performance. World Archaeology 46: 178-91.

https://doi.org/10.1080/00438243.2014. 883938

Price, T.D., C. Arcini, I. Gustin, L. Drenzel \& S. Kalmring. 2018. Isotopes and human burials at Viking Age Birka and the Mälaren region, east central Sweden. Journal of Anthropological Archaeology 49: 19-38. https://doi.org/10.1016/j.jaa.2017.10.002

Raffield, B., N. Price \& M. Collard. 2018. Polygyny, concubinage and the social lives of 
women in Viking Age Scandinavia. Viking and Medieval Scandinavia 13: 165-209. https://doi.org/10.1484/J.VMS.5.114355

Reeder, G. 2008. Queer Egyptologies of Niankhthnum and Khnumhotep, in K.M. Cooney \& C. Graves-Brown (ed.) Sex and gender in Ancient Egypt: 'Don your wig for a joyful hour’: 143-55. Swansea: Classical Press of Wales. https://doi.org/10.2307/j.ctvvn98c.12

Ringstedt, N. 1997. The Birka chamber-graves: economic and social aspects. Stockholm: Stockholm University.

Roesdahl, E. 2016. The Vikings. London: Penguin.

Sayer, D. \& H. Williams (ed.). 2009. Mortuary practices and social identities in the Middle Ages. Exeter: Exeter University Press.

SElling, D. 1940. Svenska spelbräden från vikingatid. Fornvännen 35: 134-44.

Solli, B. 2002. Seid: myter, sjamanisme og kjønn $i$ vikingenes tid. Oslo: Pax.

Sørensen, P.M. 1983. The unmanly man: concepts of sexual defamation in early northern society. Odense: Odense University Press.

Stolpe, H. 1870-1888. Birka excavation drawings, notebooks and diaries in manuscript. Twenty volumes plus six manuscripts and plans, stored in the Antiquarian Topographical Archives in Stockholm. Available at: http://historiska.se/birka/digitala-resurser/ arkivmaterial/hjalmar-stolpes-gravdagbocker (accessed 7 January 2019).

- 1879. Berättelse om de under år 1878 utförda undersökningarna på Björkö i Mälaren. Manuscript in the Antiquarian Topographical Archives, Stockholm. Available at: http://historiska.se/birka/digitala-resurser/filer/ pdf/Stolpe1878.pdf (accessed 7 January 2019).

Svanberg, F. 2003. Death rituals in south-east Scandinavia, AD 800-1000. Lund: Lund University.

Thålin-Bergman, L. 1986. Die Waffengräber von Birka, in G. Arwidsson (ed.) Birka II: 2 Systematische Analysen der Gräberfunde: 5-10. Stockholm: Vitterhetsakademien.

Thunmark-Nylén, L. (ed.). 1981. Vikingatidens $A B C$. Stockholm: National Historical Museum.

WhitTaker, H. 2006. Game-boards and gaming-pieces in funerary contexts in the Northern European Iron age. Nordlit 20: 103-12. https://doi.org/10.7557/13.1802

Wylie, A. 1992. The interplay of evidential constraints and political interests: recent archaeological research on gender. American Antiquity 57: 15-35. https://doi.org/10.2307/2694833

Williams, H. 2006. Death and memory in early medieval Britain. Cambridge: Cambridge University Press. https://doi.org/10.1017/CBO9780511489594

Received: 8 May 2018; Revised: 11 September 2018; Accepted: 4 October 2018

(C) Antiquity Publications Ltd, 2019 